\title{
A fiscal job? An analysis of fiscal policy and the labor market
}

\author{
Elva Bova ${ }^{*}$, Christina Kolerus and Sampawende J.A. Tapsoba
}

\author{
* Correspondence: ebova@imf.org \\ International Monetary Fund, 1900 \\ Pennsylvania Avenue NW, \\ Washington, DC 20431, United \\ States
}

\begin{abstract}
This paper examines the role of fiscal policies in the dynamics of the labor market. Through the lenses of Okun's Law, we assess how fiscal policy instruments as well as fiscal consolidation and expansion episodes affect labor market outcomes. Using a panel of 34 OECD countries over the period 1985-2013, we find that fiscal consolidation has a sizeable, positive and robust impact on the Okun's coefficient. This effect is particularly strong for expenditure based consolidations, suggesting that a reduction in the size of the government increases the responsiveness of employment to output and is not altered by an expansionary or recessionary position in the business cycle. Interestingly, we find no impact of fiscal expansion on the Okun's coefficient nor for specific fiscal instruments.

JEL classification: E24; E32; E62

Keywords: Okun's Law; Fiscal policy
\end{abstract}

\section{Introduction}

The global financial crisis has left its marks on labor market conditions in many advanced economies. Unemployment increased significantly in the OECD, adding eight million unemployed from 2008 to 2014 (Fig. 1); improvements in labor markets over the past years have been uneven (Fig. 2). The years of the crisis challenged policy makers in addressing unemployment and triggered a series of old and new policy responses aimed at containing job losses through setting incentives for both labor demand and supply (IMF 2010, IMF 2012, OECD 2009). Further, fiscal policy was tilted toward supporting jobs by stimulating aggregate demand.

The objective of this paper is to examine the role of fiscal policies in the dynamics of the labor market. It assesses how fiscal policy instruments and events (consolidation and expansion) affect labor market outcomes. Traditionally the literature has addressed the role of fiscal policy for employment either as a derivate of the output multiplier literature or through studies on the impact of specific fiscal policy instruments, such as labor taxation and unemployment benefits. Against this literature, we provide an innovative angle to the analysis by examining the interplay of fiscal policy, employment and output through the lenses of Okun's Law. Observed first in the early 1960s, Okun's Law captures the empirical regularity between employment (unemployment) and output, whereby output expansions are associated by employment expansions (or unemployment reductions).

(c) 2015 Bova et al. This is an Open Access article distributed under the terms of the Creative Commons Attribution License (http:// creativecommons.org/licenses/by/4.0), which permits unrestricted use, distribution, and reproduction in any medium, provided the original work is properly credited. 


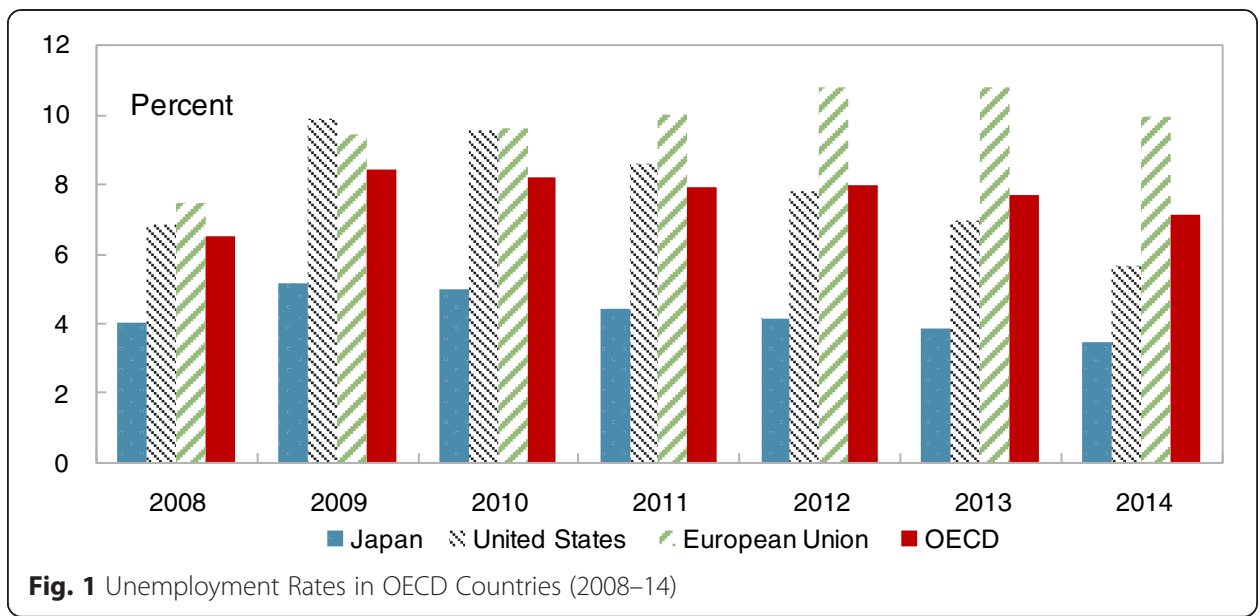

While a broad set of the literature examines the role of labor market institutions in reducing the Okun's coefficient, not much evidence has been provided on the role played by fiscal variables, namely fiscal policy instruments and episodes of fiscal expansions or fiscal consolidation. To this end, this study re-addresses the issue of the stability of Okun's Law by looking at the role played by fiscal policy. Precisely, we investigate whether fiscal and labor market policies can alter the responsiveness of employment gaps to output gaps.

Using a panel of 34 OECD countries over the period 1985-2013, we calculate timevarying Okun's coefficients for each country. We first document variations over time and across countries of Okun's coefficients. Then, we estimate how these coefficients are affected by fiscal policy - spending as well as tax components - and by fiscal events - consolidation and expansions. We also control for the phases of the business cycle by analyzing the responsiveness at times of positive and negative

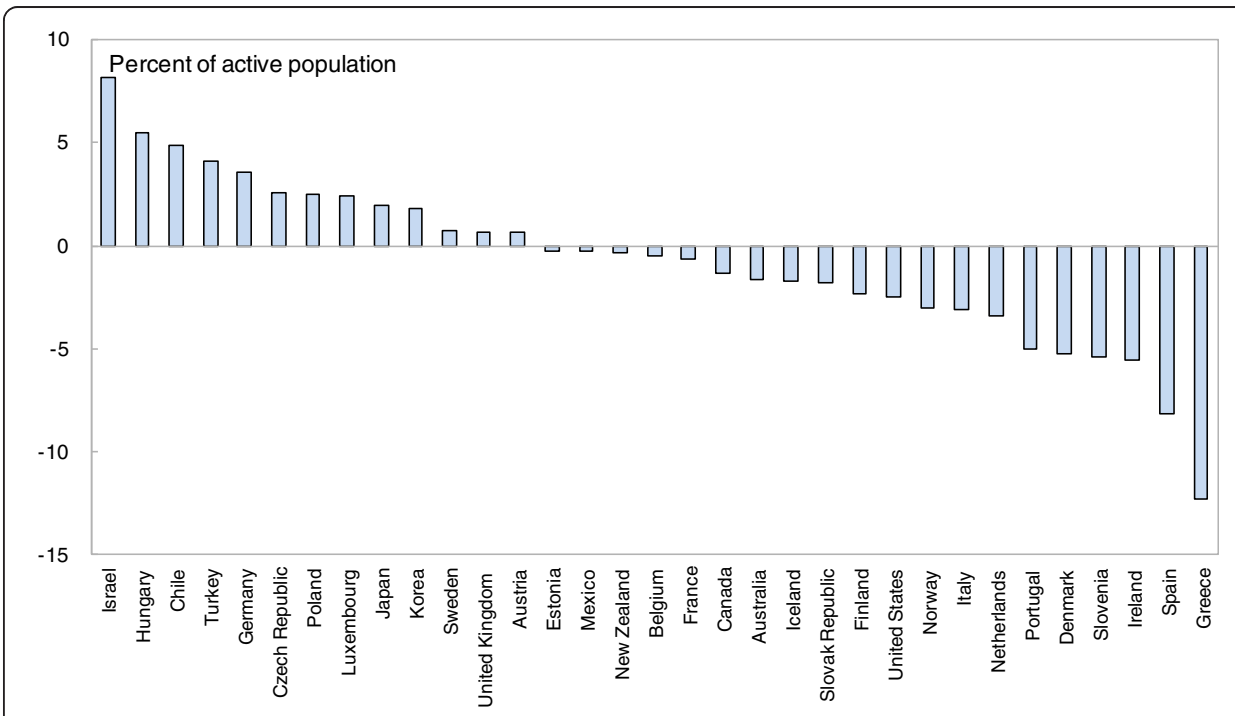

Fig. 2 Differences in Employment Rates Between September2014 and September 2008 
output gaps. In line with the relevant literature, we examine the role played by labor market policies and institutions - active and passive labor market policies as well as employment protection legislation and include a monetary policy variable.

The key findings are as follows. Okun's coefficients display large heterogeneity across countries and over time. We find no impact of specific fiscal instruments on the Okun's coefficient, suggesting that increasing or reducing total spending or some spending components and increasing or reducing tax rates would not alter the way employment reacts to output. Against this, we find that fiscal consolidation has a sizeable, positive and robust impact on the coefficient, suggesting that increasing tax revenues or reducing the size of the government by reducing spending enhances the responsiveness of employment to output. Interestingly, we find no impact of fiscal expansion on the Okun's coefficient. We further find that the impact of fiscal consolidation on the Okun's coefficient does not change according to the phases of the business cycle.

This finding suggests that during a consolidation episode, employment tends to be more reactive to output than in normal times. If output is expanding then employment would expand more than in normal times, while if output is contracting, employment would contract more than in normal times. Hence, consolidating in good times (during output expansion) is here found to positively affect employment. The result is robust under a specification which includes the duration of the consolidation episode, expressed in number of years. Further, distinguishing between expenditure-driven and revenuedriven consolidation episodes, we find that the Okun's coefficient is sensitive only to expenditure reduction and not increases in revenue. This is an interesting result which may highlight the presence of a crowding-in effect for the private sector when the government size in the economy shrinks. Yet an analysis of the change in the composition of spending during consolidation is necessary to accurately interpret the finding in light of a crowding-in effect for the private sector.

Finally, we confirm the finding of the literature that employment protection legislation weakens the responsiveness of employment to changes in output. In addition, we find that active labor market policies magnify this impact, while unemployment benefits and early retirement benefits do not alter the Okun's coefficient. We also find that monetary policy, here captured by the central bank money rate, has a negative impact on the coefficient. This result could capture changes in labor demand not due to output but rather caused by increases in the cost of capital relative to labor.

The remainder of the paper is structured as follows. Section II provides a review of the literature on the stability of the Okun's Law and on the way fiscal policy can impact the labor market; Section III presents the empirical analysis, including model specification, data and estimation results; Section IV concludes.

\section{Literature review}

\subsection{Stability of Okun's coefficient}

In his study of the United States unemployment dynamics for the period 1947-60, Okun (1962) finds that a $1 \%$ increase in Gross National Product (GNP) corresponds to a 0.3 percentage point decrease in the unemployment rate. This co-movement between output and unemployment results from the fact that variations in output make firms hire and fire workers, causing changes in employment and unemployment (Ball et al. 
2013). Okun's coefficient reflects the degree of adjustment of employment to changes in output, which in turn can depend on labor market rigidities and institutions, technological and training costs or costs created by employment protection laws. Accordingly, some countries might exhibit different coefficients related to their own characteristics. For instance, Ball et al. (2013) find an Okun's coefficient as high as 0.8 for Spain, probably reflecting a large number of temporary workers, and a coefficient of 0.15 for Japan, possibly resulting from the large use of permanent contracts and adjustments in wage and bonus payments instead of lay-offs.

Although more an empirical regularity than a theoretical construct, Okun's Law has featured well as a forecasting instrument for employment dynamics in advanced economies (Ball et al. 2013). Yet labor market developments prevailing during the global financial crisis have put the stability of Okun's Law under question (Gordon 2010; Daly and Hobijn 2010; Cazes et al. 2012; Daly et al. 2014). This debate emerged, in particular, from the observation that increases in unemployment in most advanced markets were found to be larger than those expected under the Law. Some studies associated this fact with changes in productivity (Gordon 2010; Daly and Hobijn 2010) and others have put forward the argument of jobless recoveries (Jaimovich and Siu 2012; ILO 2014), acknowledging deviations from Okun's Law.

The discussion on the over-time and cross-country stability of Okun's Law is long dated. The literature has commonly explained the heterogeneity (by country and over time) by differences in labor market institutions, including the degree of protection and difficulty at which workers can be hired or laid off, changes in productivity, and the elasticity of the labor force to output. Employment protection legislation is found to be behind diverging changes in the Okun's coefficient during the crisis (Cazes et al. 2013). Soegner and Stiassny (2002) examine the stability of Okun's coefficients across 15 OECD countries over 1960-99 by means of Bayesian econometrics and Kalman filtering and find that the heterogeneity across countries and over time is explained by different degrees of labor market protection. Against these studies, Ball et al. (2013) find a strong and stable relationship in most countries, but sizeable variations across countries explained by national labor market characteristics other than employment protection legislation. They justify the break during the crisis by the fact that output grew more slowly in recent recoveries than in earlier ones and find that unusual changes in productivity or in labor force participation were relatively small.

Several studies provide evidence that productivity dynamics can explain changes in the coefficients. By decomposing output, Gordon (2010) finds that changes in the relationship between output, hours and productivity contributed to jobless recoveries after 2000. Daly and Hobijn (2010) find that the main factor driving the unusual rise in the United States unemployment relative to output during the financial crisis was very rapid productivity growth which allowed businesses to cut back sharply on labor while maintaining output levels. Similarly, by decomposing Okun's coefficient, Daly et al. (2013) provide evidence that productivity is more procyclical in recessions than in normal times, reflecting greater variation in factor utilization around these times. The procyclicality of Okun's coefficient vis-à-vis the business cycle has been confirmed by Owyang and Sekhposyan (2012) who also find that periods of high unemployment are found to be correlated with increased sensitivity of the unemployment rate to 
output growth or gap fluctuations. Finally, Knotek (2007) finds the Okun's coefficient for the United States to be smaller (in absolute value) during expansions than recessions.

\subsection{Fiscal policy and employment}

In classical labor market models, labor demand identifies the number of workers (or working hours) firms are willing to hire at any given rate of the real wage. Hiring decisions depend on a firm's profit maximization function and are thus determined by the level of real wages, the marginal productivity of labor vis-à-vis the capital stock and the level of technology. The labor supply identifies, instead, the number of workers willing to supply labor at each level of the real wage by maximizing workers' utility derived from leisure activities and the consumption of goods and services. Within these dynamics, fiscal policy can indeed affect firms and workers' decisions, thereby boosting labor demand and supply, or the structure of the labor market, removing frictions and promoting skills. This can be done through higher spending, lower taxes, or alternatively through ad hoc measures that improve the matching of workers with existing job vacancies and create incentives to work (Bassanini and Duval 2006; Estevão 2007; Card et al. 2010; IMF 2012; and Orlandi 2012).

The literature has addressed employment effects of fiscal policy from different dimensions. On the one hand, the fiscal multiplier literature has examined the macroeconomic impact of government spending (usually spending on goods and services) on employment as a derivate of the impact on output. On the other hand, microeconomic studies have investigated the effect of specific tax changes and government benefits on labor demand and supply dynamics.

On the expenditure side, the literature documents a positive effect of public spending on labor market outcomes. This effect operates mainly through aggregate demand: spending on goods and services and capital spending directly affect aggregate demand and through this labor demand. The impact of the wage bill is instead more direct, as the public sector is often the largest employer in the country. For the United States, studies find positive effects on employment following a government spending shock (Fatás and Mihov 2001; Burnside et al. 2004; Cavallo 2005; Gali et al. 2003). In particular, Monacelli et al. (2010) provide an empirical estimate of the unemployment multipliers of government spending, focusing in more detail on the transmission of fiscal policy to the labor market. They show that an increase in government expenditure boosts total hours, employment and the job finding probability. In a real business cycle model with competitive labor markets and lump-sum taxation, Finn (1998) suggests that an increase in government employment could lead to lower private sector employment (if the wealth effect is small) and higher real wages as well as lower private sector hours, output and investment. However, Lane and Perotti (2003) and Alesina et al. (2002) find evidence of the opposite impact. They show that an increase in government purchases and the wage bill leads to higher wages in the private sector, lower firm profits and ultimately lower employment and business investment in current and future periods. As a result, output, household income and private consumption expenditure contract. ${ }^{1}$

Still within spending, it is usually acknowledged that social benefits weaken the link between labor supply and salaries (Nickell 1998; Nunziata 2002; Bassanini and Duval 2006; IMF 2012) by making labor more costly and reducing labor demand. Social 
assistance can reduce work incentives, especially if benefits are withdrawn as earnings rise. Duval and Bassanini estimate that a $10 \%$ increase in unemployment benefits would increase unemployment by 1.2 percentage points. Krueger and Meyer (2002) conclude that a $10 \%$ increase in unemployment benefits raises the average duration of unemployment by around $5 \%$-although this impact is likely to be much higher in countries with relatively weak eligibility conditions. In the same vein, pension benefits (usually the largest share of social benefits) tend to affect pension decisions and a higher number of retirees would reduce the labor force and employment. Empirical evidence also suggests that strengthening the link between contributions and benefits improves labor market outcomes (Disney 2004).

On the revenue side, the literature agrees that labor taxes, including personal income tax and social security contributions, negatively affect employment by influencing both labor supply and demand. If the substitution effect prevails, higher taxes reduce aftertax wages for workers who then supply less work as the incentive to opt for leisure as opposed to work is now higher. Higher taxes on labor income can also reduce labor demand by making labor more costly (Bassanini and Duval 2006). Whether the tax burden is borne rather by workers than by firms ultimately depends on the price-elasticities of labor supply and labor demand. For instance, Cahuc and Zylberberg (2004) find that the price elasticity of labor demand is close to about 1 , while the elasticity of labor supply to real wages is found to be between 0.2 and $0.5 \%$ (IMF 2012).

Corporate taxes can affect employment by reducing investment and production and by reducing labor supply to the extent that firms pass on these taxes to employees in the form of lower wages. For instance, business tax relief can ease financing constraints for firms relying on retained earnings and boost investment (IMF 2012). These effects are consistent with the finding that reductions in the cost of capital reduce unemployment (Phelps 1994; Blanchard 1997). Likewise, taxes on final consumption (VAT, excises) increase the costs for consumption goods thereby reducing real wages, which, if the substitution effect prevails over the wealth effect, would lower the labor supply at a given reservation wage (IMF 2012).

Given prevailing elasticities, overall, compositional shifts of taxes from labor to consumption taxes could boost labor demand. For instance, reductions in employer social security contributions financed by higher consumption taxes (as in a fiscal devaluation case) can raise labor demand by lowering (non-wage) labor costs (De Mooij and Keen 2013). The long-term employment effects of tax shifts depend on the extent to which the tax burden is shifted away from labor income and onto other incomes. Although increasing in number, studies on the impact of fiscal consolidations on employment are still few (Daly et al. 2013; Turrini 2013; Jalles 2014; and Woo et al. 2013), and, to our knowledge, only one study has at present examined the implication of consolidations or expansions on the Okun's Law. Using the Devries et al. (2011) database for European countries, Turrini (2013) finds a temporary impact of fiscal consolidation on cyclical unemployment, which is mainly due to expenditure measures and is higher for countries with lower employment protection. Woo et al. (2013) find that increases in unemployment are a major channel through which fiscal consolidations can affect inequality. Using Ramey's (2011) definition of fiscal expansion, Daly et al. (2013) examine responses of the Okun's coefficients to a fiscal expansion shock in the United States. They find a small output reaction and no adjustment in employment but in hours 
worked, possibly on account of the fact that the shock is considered to be very temporary.

\section{Empirical strategy}

\subsection{Methodology}

To assess the impact of fiscal policies on employment, we base our analysis on the short-term relationship between employment gaps and output gaps, used as one of the two main specifications for Okun's Law. ${ }^{2}$ We adopt a two-step approach.

In the first step, we estimate a time-varying Okun's Law coefficient for each country. The time-varying and country-specific impact of the output gap on the employment gap is derived following the model specification below.

$$
e_{i t}=\alpha_{i t}+\beta_{i t} y_{i t}+\eta_{i t}
$$

$e_{i t}$ denotes the employment gap of country $I$ at time $t$, calculated as the deviation of current employment from its trend; $y_{i t}$ is the output gap, obtained as the deviation of actual output from potential output. The employment trend (or long-term level) and potential output were calculated using Hodrick-Prescott filtering. We use 6.25 as a smoothing parameter for the results reported below, with no significant change when applying other parameters. $\alpha_{i t}$ and $\beta_{i t}$ are time-varying intercept and Okun's coefficient, and $\eta_{i t}$ is the error term. Equation (1) is estimated using local Gaussian-weighted ordinary least squares (see Aghion and Marinescu 2008). This technique determines the time-varying Okun's coefficient $\hat{\beta}_{i t}$ for country $i$ at year $t$ by using all observations over the available time span and assigning greater weights to those observations closest to the reference year. This is achieved by giving a Gaussian-centered weight to the reference period. If $\tau$ denotes the length of the rolling window, then the error term $\vartheta_{i t}$ follows a normal distribution function:

$$
N\left(0, \sigma^{2} / w_{t}(\tau) \text { with } w_{t}(\tau)=\frac{1}{\sigma \sqrt{ }(2 \Pi)} \exp \left(-\frac{(\tau-t)^{2}}{2 \sigma^{2}}\right), \tau \in(t-5, t+4)\right)
$$

The smoothing parameter $\sigma$ is arbitrarily set to 3 as the results are qualitatively robust to slight changes of this parameter.

In the second step, the coefficients $\hat{\beta}_{i t}$ are regressed on fiscal variables. This is represented in equation (3) below.

$$
\hat{\beta}_{i t}=\gamma+\delta^{F} F I_{i, t}^{F}+\sum_{j=1}^{J} \lambda_{j} X_{j i t}+\theta_{i}+\theta_{t}+\varepsilon_{i t^{\prime}}
$$

where $F I_{i, t}^{F}$ denotes the respective fiscal instrument, $\delta^{F}$ captures the impact of the fiscal instrument under consideration on the Okun's coefficient and $X_{j}$ represents control variables including the stance of monetary policy (primarily the central bank policy rate and, when unavailable, the money market rate or the long-term bond yield) and the degree of labor market regulations. Changes in the interest rate may affect the cost of labor relative to capital and hence make employment more or less reactive to changes in aggregate demand. We also control for differences in the flexibility of the labor market (employment protection legislation), which is usually found in the literature to negatively affect the Okun's coefficient. $\theta_{i}$ and $\theta_{t}$ are the country and year fixed effects, respectively. $\varepsilon_{i t}$ is the classic error term. 
We further explore the role of fiscal consolidation and expansion after controlling for other potential relevant drivers of the Okun's coefficient. This is formulated in it's equation (4) below.

$$
\hat{\beta}_{i t}=\gamma+\delta^{C} F_{i, t}^{C}+\delta^{E} F_{i, t}^{E}+\sum_{j=1}^{J} \lambda_{j} X_{j i t}+\theta_{i}+\theta_{t}+\varepsilon_{i t}
$$

$F_{i, t}^{C}$ denotes fiscal consolidation and $F_{i, t}^{E}$ fiscal expansion. $\delta^{C}$ and $\delta^{E}$ capture the respective effects of fiscal consolidation and fiscal expansion the Okun's coefficient. The rest of the variables are defined as above.

Equations (3) and (4) are estimated with the Weighted Least Squares technique using the inverse of the standard deviation of $\hat{\beta}_{i t}$. Estimates are corrected for heteroscedasticity and autocorrelation at the country level using the robust and cluster options. In addition, we correct for the fact that the first stage is estimated by using the Weighted Least Squares technique with the inverse of the standard deviation of the first step. An intercept is included in all regressions.

\subsection{Discretionary fiscal policy}

There is, however, a major challenge in correctly identifying the role of fiscal policy on employment. Fiscal policy instruments and employment gaps can be endogenous, as changes in employment can trigger immediate fiscal policy responses. To solve for the endogeneity in government expenditures, we follow the relevant literature including Fatas and Mihov (2003, 2006), Afonso et al. (2010), and Agnello et al. (2013). ${ }^{3}$ Discretionary fiscal policy is calculated by extracting the automatic stabilizer component of public spending. To this end, we estimate a linear "fiscal rule" for each country where the fiscal balance $\left(F_{i t}\right)$ is expressed as function of its lagged value $\left(F_{\mathrm{it}-1}\right)$, inflation $\left(\pi_{i t}\right)$, output gap $\left(\mathrm{y}_{i t}\right)$, debt $\left(\right.$ Debt $\left._{i t}\right)$, and a time trend $(T t)$ :

$$
F_{i t}=\gamma_{0}+\gamma_{1} F_{i t-1}+\gamma_{2} \pi_{i t}+\gamma_{3} \pi_{i t}^{2}+\gamma_{4} y_{i t}+\gamma_{5} \operatorname{Debt}^{2}{ }_{i t}+\gamma_{6} T_{t}+\mathcal{T}_{i t}
$$

The residual $\mathcal{T}_{i t}$ is then taken as the proxy for discretionary policy. The underlying idea is that after accounting by country and for each variable that captures the conditions of the business cycles, the remaining portion is a good proxy of fiscal activism. Further, we include lags to solve for endogeneity in tax items and use panel fixed effects to control for the simultaneous bias. Moreover, estimated as a residual, $\mathcal{T}_{i t}$ is trend stationary.

\subsection{Data}

For the purpose of the analysis, we collect data for a panel of 34 OECD countries for the period 1985-2013. Data on employment, on real GDP and public spending items are from the IMF World Economic Outlook (WEO) database. Tax rates are from Ilzetzki's (2011) database, which has observations for 15 countries for the period 1981-2008. ${ }^{4}$ Data on the central bank policy rate, money market rate and long-term bond yield are from the IMF-International Finance Statistics (IFS) database. Data on employment protection legislation and on spending on labor market policies, both active and passive, are from the OECD, expressed as percent of GDP. For fiscal consolidations (and expansions) we create dummies using the definition of consolidations provided by Giavazzi and Pagano (1996) and Alesina and Ardagna (1998) following Jalles (2014). For Giavazzi and Pagano, a fiscal 
Table 1 Okun's coefficient by country (1985-2013)

\begin{tabular}{|c|c|c|c|c|}
\hline \multirow[t]{2}{*}{ Country } & \multicolumn{4}{|c|}{ Okun's coefficient (employment) } \\
\hline & $\beta$ & $\mathrm{SD}(\beta)$ & Observations & R2 \\
\hline United States & $0.422^{* * *}$ & $(0.0386)$ & 45 & 0.723 \\
\hline United Kingdom & $0.298^{* * *}$ & $(0.0546)$ & 45 & 0.443 \\
\hline Austria & $0.234^{* * *}$ & $(0.0343)$ & 45 & 0.468 \\
\hline Belgium & $0.247^{* * *}$ & $(0.0346)$ & 45 & 0.502 \\
\hline Denmark & $0.342^{* * *}$ & $(0.0731)$ & 45 & 0.373 \\
\hline France & $0.191^{* * *}$ & $(0.0397)$ & 45 & 0.297 \\
\hline Germany & $0.343^{* * *}$ & $(0.0615)$ & 45 & 0.533 \\
\hline Italy & $0.160 * * *$ & $(0.0419)$ & 45 & 0.209 \\
\hline Luxembourg & $0.151^{* * *}$ & $(0.0512)$ & 45 & 0.180 \\
\hline Netherlands & $0.318^{* * *}$ & $(0.0578)$ & 35 & 0.372 \\
\hline Norway & $0.323^{* * *}$ & $(0.0725)$ & 45 & 0.311 \\
\hline Sweden & $0.351^{* * *}$ & $(0.0743)$ & 45 & 0.338 \\
\hline Switzerland & $0.271^{* * *}$ & $(0.0590)$ & 45 & 0.252 \\
\hline Canada & $0.423^{* * *}$ & $(0.0401)$ & 45 & 0.694 \\
\hline Japan & $0.156^{* * *}$ & $(0.0244)$ & 45 & 0.391 \\
\hline Finland & $0.398^{* * *}$ & $(0.0668)$ & 45 & 0.582 \\
\hline Greece & $0.160^{* *}$ & $(0.0764)$ & 45 & 0.135 \\
\hline Iceland & $0.934^{* *}$ & $(0.445)$ & 45 & 0.095 \\
\hline Ireland & $0.463^{* * *}$ & $(0.0684)$ & 45 & 0.515 \\
\hline Portugal & $0.276^{* * *}$ & $(0.0838)$ & 45 & 0.316 \\
\hline Spain & $0.606^{* * *}$ & $(0.0836)$ & 45 & 0.667 \\
\hline Turkey & 0.00188 & $(0.0590)$ & 38 & 0.000 \\
\hline Australia & $0.461^{* * *}$ & $(0.0602)$ & 45 & 0.494 \\
\hline New Zealand & $0.305^{* *}$ & $(0.145)$ & 45 & 0.117 \\
\hline Chile & $0.220^{* * *}$ & $(0.0201)$ & 45 & 0.626 \\
\hline Mexico & $0.164^{* * *}$ & $(0.0358)$ & 35 & 0.261 \\
\hline Israel & $0.168^{* * *}$ & $(0.0595)$ & 37 & 0.147 \\
\hline Korea & $0.232^{* * *}$ & $(0.0503)$ & 45 & 0.452 \\
\hline Czech Republic & 0.116 & $(0.0750)$ & 20 & 0.163 \\
\hline Slovak Republic & $0.231 * * *$ & $(0.0604)$ & 22 & 0.414 \\
\hline Estonia & $0.313^{* * *}$ & $(0.0623)$ & 22 & 0.626 \\
\hline Hungary & $0.285^{* * *}$ & $(0.0721)$ & 35 & 0.417 \\
\hline Slovenia & $0.241^{* *}$ & $(0.0861)$ & 23 & 0.344 \\
\hline Poland & $0.188^{* * *}$ & $(0.0664)$ & 31 & 0.229 \\
\hline Panel Estimate & $0.273^{* * *}$ & $(0.0499)$ & 1378 & 0.122 \\
\hline
\end{tabular}

Note: Robust standard errors in parentheses ${ }^{* * *} \mathrm{p}<0.01,{ }^{* *} \mathrm{p}<0.05,{ }^{*} \mathrm{p}<0.1$

Country and year fixed effects are controlled for in the panel estimate

episode consists of a change in the cyclically-adjusted primary balance (CAPB) of at least $2 \%$ of GDP in 1 year or at least $1.5 \%$, on average, in the last 2 years. Alesina and Ardagna, instead, consider a limit of 3 percentage points of GDP for a single year consolidation and cumulative changes in the CAPB that are at least 5, 4, 3 percentage points of GDP in, respectively, 4, 3 or 2 years, or 3 percentage points in one year. 


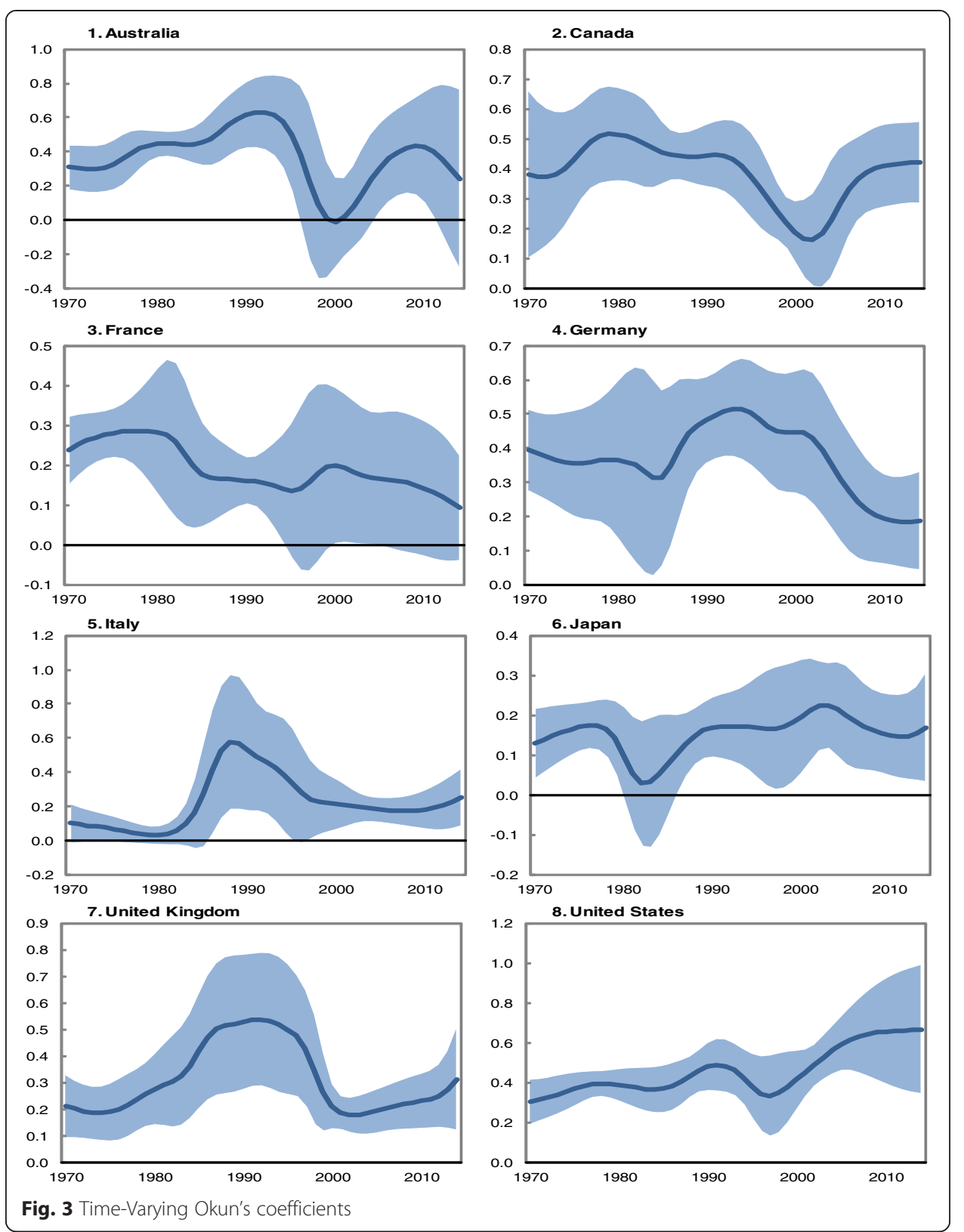

\section{Results}

\subsection{Evidence on Okun's coefficient heterogeneity}

We first provide evidence on the heterogeneity of the Okun's coefficient over time and across countries. Table 1 reports the Okun's coefficients obtained by regressing output gaps on employment gaps over the period 1985-2013. Cross-country differences are sizeable. The coefficient ranges from 0.15 for Luxemburg to 0.93 for Iceland, and it is insignificant for Turkey and the Czech Republic, but positive and significant for all other countries.

Figure 3 reports the time-varying Okun's coefficients for the G-8 economies. It shows large variations for each country over time. Employment's reaction to output appears relatively moderate in most countries and particularly low in Japan, Italy, the United 
Table 2 Time-varying Okun's coefficient and fiscal policy instruments

\begin{tabular}{|c|c|c|c|c|c|c|c|c|c|c|c|c|}
\hline & Time-varyin & kun's coeffi & nt (employm & & & & & & & & & \\
\hline Central Bank policy rate $(-1)$ & $\begin{array}{l}(1) \\
-0.257^{* *} \\
(0.119)\end{array}$ & $\begin{array}{l}(2) \\
-0.318^{*} \\
(0.158)\end{array}$ & $\begin{array}{l}(3) \\
-0.493^{* * *} \\
(0.173)\end{array}$ & $\begin{array}{l}(4) \\
-0.492^{* * *} \\
(0.174)\end{array}$ & $\begin{array}{l}(5) \\
-0.164 \\
(0.421)\end{array}$ & $\begin{array}{l}(6) \\
-0.224 \\
(0.409)\end{array}$ & $\begin{array}{l}(7) \\
-0.227 \\
(0.445)\end{array}$ & $\begin{array}{l}(8) \\
-0.567 \\
(0.478)\end{array}$ & $\begin{array}{l}(9) \\
-0.234^{* * *} \\
(0.046)\end{array}$ & $\begin{array}{l}(10) \\
-0.440 \\
(0.391)\end{array}$ & $\begin{array}{l}(11) \\
-0.469 \\
(0.395)\end{array}$ & $\begin{array}{l}(12) \\
-0.392 \\
(0.379)\end{array}$ \\
\hline Employment Protection & $\begin{array}{l}-0.107^{* * *} \\
(0.038)\end{array}$ & $\begin{array}{l}-0.111^{* *} \\
(0.049)\end{array}$ & $\begin{array}{l}-0.086 \\
(0.091)\end{array}$ & $\begin{array}{l}-0.085 \\
(0.091)\end{array}$ & $\begin{array}{l}-0.660^{*} \\
(0.314)\end{array}$ & $\begin{array}{l}-0.644^{*} \\
(0.329)\end{array}$ & $\begin{array}{l}-0.667^{* *} \\
(0.302)\end{array}$ & $\begin{array}{l}-0.384 \\
(0.330)\end{array}$ & $\begin{array}{l}-0.112^{*} \\
(0.062)\end{array}$ & $\begin{array}{l}-0.0931^{*} \\
(0.047)\end{array}$ & $\begin{array}{l}-0.100^{* *} \\
(0.047)\end{array}$ & $\begin{array}{c}-0.086^{*} \\
(0.0444)\end{array}$ \\
\hline Discretionary expenditure & & $\begin{array}{c}0.149 \\
(0.262)\end{array}$ & & & & & & & & & & \\
\hline Discretionary current exp. & & & $\begin{array}{c}0.298 \\
(0.188)\end{array}$ & & & & & & & & & \\
\hline Discretionary capital exp. & & & & $\begin{array}{l}0.0115 \\
(0.298)\end{array}$ & & & & & & & & \\
\hline PIT rate $(-1)$ & & & & & $\begin{array}{c}0.118 \\
(0.127)\end{array}$ & & & & & & & \\
\hline VAT rate $(-1)$ & & & & & & $\begin{array}{l}-0.498 \\
(0.450)\end{array}$ & & & & & & \\
\hline CIT rate $(-1)$ & & & & & & & $\begin{array}{c}0.204 \\
(0.221)\end{array}$ & & & & & \\
\hline SSR rate $(-1)$ & & & & & & & & $\begin{array}{l}-0.166 \\
(0.167)\end{array}$ & & & & \\
\hline Tax wedge rate $(-1)$ & & & & & & & & & $\begin{array}{l}-0.148 \\
(0.256)\end{array}$ & & & \\
\hline LMP & & & & & & & & & & $\begin{array}{c}4.741 \\
(2.832)\end{array}$ & & \\
\hline PLMP & & & & & & & & & & & $\begin{array}{l}3.667 \\
(3.100)\end{array}$ & \\
\hline ALMP & & & & & & & & & & & & $\begin{array}{l}15.54^{* *} \\
(6.488)\end{array}$ \\
\hline Observations & 753 & 634 & 509 & 509 & 231 & 231 & 231 & 190 & 400 & 604 & 645 & 604 \\
\hline R-squared & 0.748 & 0.801 & 0.819 & 0.818 & 0.731 & 0.733 & 0.733 & 0.736 & 0.916 & 0.763 & 0.735 & 0.771 \\
\hline Number of code & 34 & 34 & 29 & 29 & 14 & 14 & 14 & 13 & 34 & 32 & 32 & 32 \\
\hline
\end{tabular}

Note: Robust standard errors in parentheses

${ }^{* * *} p<0.01,{ }^{* *} p<0.05,{ }^{*} p<0.1$ 
Kingdom and the United States. During the 1990s, some countries experienced sharp increases in the sensitivity of employment to output, namely Australia, Germany, Italy, Japan and the United Kingdom. From the 2000s onwards, most countries see their Okun's coefficients increasing, with the exception of Germany and France.

\subsection{Econometric results}

By regressing time-varying Okun's coefficients on fiscal policy instruments we find no significant impact (Table 2). The monetary policy rate and employment protection legislation, when significant, have a negative impact on the Okun's coefficient. For the monetary policy rate, this could be interpreted as the impact that higher interest rates have on labor demand independently from the aggregate demand, and possibly induced by changes in the capital-to-labor ratio, as the cost of capital increases relative to labor. The sign for the employment protection legislation is in line with what is found in the literature and suggests that higher protection loosens the link between workers and firms. Finally, we find that active labor market policies (including training, job rotation and rehabilitation) are significant and positive, implying that under these policies the responsiveness of employment to aggregate demand increases. This finding corroborates the argument put forward in favor of active labor policies and against passive labor policies, like unemployment benefits, which may distort incentives to improving employability, taking up a job or searching actively.

Looking at fiscal episodes, we find that fiscal consolidation significantly affects the Okun's coefficient by increasing the responsiveness of employment gaps to output gaps (Table 3). However, fiscal expansions have no impact. On average, the estimated Okun's coefficient is 0.273 , implying that a 3 percent improvement in output gap would translate into an improvement of the employment gap by 0.8 percentage points and vice versa during recession periods. All other things being equal, fiscal consolidation improves the Okun's coefficient by 0.05 to 0.323 . Accordingly, a $3 \%$ improvement in output gap would translate into to an improvement of the employment gap by 1 percentage point and vice versa during recession periods. The employment gain on the labor market from fiscal consolidation during boom times is approximately 0.2 percentage points. Also, fiscal consolidations when interacted with output expansions (columns 3 and 5) have no different impact, suggesting that the phase of the cycle does not matter for the impact. The finding on consolidations bears important policy implications. As the impact is insensitive to the phase of the cycle, consolidation would harm employment during recessions and would benefit employment during expansions. Employment protection legislation is always strongly significant and negative as predicted, while the significance of monetary policy rate is somehow weaker than in the previous regression.

Table 4 reports the impact of the duration of fiscal episodes, where duration captures the number of years of the episode. Results show that the duration of fiscal consolidation does matter for the impact, and, in this case too, the impact is independent from the phase of the cycle. Similarly to the previous findings, the duration of fiscal expansions does not matter for the impact, which is always insignificant.

Table 5 reports the impact of consolidation on the Okun's coefficient distinguishing between expenditure-based or revenue-based consolidations. The estimates illustrate that the impact is totally driven by expenditure-based consolidation, and, as before, it 
does not change at phases of the cycle. This suggests that during a consolidation episode the reduction of the size of the government in the economy (proxied by spending) would crowd in the private sector, making employment more reactive to output, than otherwise. An important factor underlying this finding could be associated to reductions in the size of unemployment benefits or any passive labor market policies which would make the labor market less linked to aggregate demand. Arguably, more research in this direction is needed, especially to detect what component of expenditure drives mostly the impact on the Okun's coefficient.

\section{Conclusion}

Labor market conditions across most OECD countries continue to be significantly worse than desired by society. Although policy makers and even central bankers pay close attention to movements in employment and unemployment, the understanding of how to influence these movements is still limited. In order to design supportive fiscal

Table 3 Time-varying Okun's coefficient and fiscal episodes

\begin{tabular}{|c|c|c|c|c|c|}
\hline & \multicolumn{5}{|c|}{ Time-varying Okun's coefficient (employment) } \\
\hline & (1) & $(2)$ & (3) & (4) & (5) \\
\hline \multirow[t]{2}{*}{ Central Bank policy rate $(-1)$} & $-0.255^{* *}$ & $-0.226^{*}$ & $-0.231^{*}$ & $-0.236^{*}$ & $-0.250^{*}$ \\
\hline & $(0.120)$ & $(0.121)$ & $(0.125)$ & $(0.119)$ & $(0.124)$ \\
\hline \multirow[t]{2}{*}{ Employment protection legislation } & $-0.108^{* * *}$ & $-0.0937^{* *}$ & $-0.0899^{* *}$ & $-0.0998^{* *}$ & $-0.0939^{* *}$ \\
\hline & $(0.0380)$ & $(0.0393)$ & $(0.0391)$ & $(0.0384)$ & $(0.0381)$ \\
\hline \multirow[t]{2}{*}{ Dummy output expansion } & 0.00552 & & 0.00499 & & 0.00360 \\
\hline & $(0.0056)$ & & $(0.00801)$ & & $(0.00646)$ \\
\hline \multirow[t]{2}{*}{ Fiscal consolidation GP } & & $0.0543^{* * *}$ & $0.0568^{* *}$ & & \\
\hline & & $(0.0189)$ & $(0.0223)$ & & \\
\hline \multirow[t]{2}{*}{ Fiscal expansion GP } & & 0.0406 & 0.0273 & & \\
\hline & & $(0.0264)$ & $(0.0253)$ & & \\
\hline \multirow[t]{2}{*}{ Fiscal consolidation GP* Output expansion } & & & -0.0039 & & \\
\hline & & & $(0.0257)$ & & \\
\hline \multirow[t]{2}{*}{ Fiscal expansion GP* Output expansion } & & & 0.0678 & & \\
\hline & & & $(0.0484)$ & & \\
\hline \multirow[t]{2}{*}{ Fiscal consolidation AA } & & & & $0.0462^{* *}$ & $0.0559^{* *}$ \\
\hline & & & & $(0.0184)$ & $(0.0228)$ \\
\hline \multirow[t]{2}{*}{ Fiscal expansion AA } & & & & 0.0325 & 0.00904 \\
\hline & & & & $(0.0221)$ & $(0.0198)$ \\
\hline \multirow[t]{2}{*}{ Fiscal consolidation $\mathrm{AA}^{*}$ Output expansion } & & & & & -0.0183 \\
\hline & & & & & $(0.0276)$ \\
\hline \multirow[t]{2}{*}{ Fiscal expansion $A A^{*}$ Output expansion } & & & & & $0.0935^{*}$ \\
\hline & & & & & $(0.0466)$ \\
\hline Observations & 753 & 747 & 747 & 747 & 747 \\
\hline R-squared & 0.748 & 0.755 & 0.758 & 0.753 & 0.758 \\
\hline Country & 34 & 33 & 33 & 33 & 33 \\
\hline
\end{tabular}

Note: Robust standard errors in parentheses

${ }^{* * *} p<0.01,{ }^{* *} p<0.05,{ }^{*} p<0.1$

GP refers to fiscal episodes captured following Giavazzi and Pagano (1996) and AA refers to fiscal episodes captured following Alesina and Ardagna (1998) 
policy to help the economy overcome mass unemployment, in particular for the young, it is crucial to understand which policy instruments could be useful.

This study investigates the impact of fiscal policy on labor market outcomes, looking at how this can affect the way employment reacts to output. To this end, we first investigate whether the relationship between output and employment, also defined as Okun's Law, has changed over time and is different across country and find heterogeneity of the Okun's coefficient. Then we test whether fiscal policy could have played a role in the way these coefficients varied over time and find that individual fiscal policy instruments, whether discretionary spending or tax rates, would not affect this relationship, but consolidation packages do. On the contrary, we find no evidence of impacts of fiscal stimulus on the Okun's coefficients. We examine how consolidations affect employment gaps and find that the impact does not change according to the phase of the cycle (whether in a recession or expansion), but it is stronger the longer the consolidation episodes and is only significant in the case of expenditure-based adjustment.

Table 4 Time-varying Okun's coefficient and duration of fiscal episodes

\begin{tabular}{|c|c|c|c|c|}
\hline & \multicolumn{4}{|c|}{ Time-varying Okun's coefficient (employment) } \\
\hline & (1) & (2) & (3) & (4) \\
\hline \multirow[t]{2}{*}{ Central Bank policy rate $(-1)$} & $-0.243^{*}$ & $-0.244^{*}$ & $-0.238^{*}$ & $-0.250^{*}$ \\
\hline & $(0.121)$ & $(0.123)$ & $(0.119)$ & $(0.123)$ \\
\hline \multirow[t]{2}{*}{ Employment protection legislation } & $-0.0968^{* *}$ & $-0.0966^{* *}$ & $-0.0945^{* *}$ & $-0.0897^{* *}$ \\
\hline & $(0.0394)$ & $(0.0394)$ & $(0.0397)$ & $(0.0396)$ \\
\hline \multirow[t]{2}{*}{ Dummy output expansion } & & 0.00559 & & 0.00344 \\
\hline & & $(0.0071)$ & & (0.0068) \\
\hline \multirow[t]{2}{*}{ Duration consolidation GP } & $0.0170^{* * *}$ & $0.0177^{* *}$ & & \\
\hline & $(0.0056)$ & $(0.0068)$ & & \\
\hline \multirow[t]{2}{*}{ Duration expansion GP } & $0.0185^{*}$ & 0.0136 & & \\
\hline & $(0.0096)$ & $(0.0127)$ & & \\
\hline \multirow[t]{2}{*}{ Duration consolidation GP* Output expansion } & & -0.00175 & & \\
\hline & & $(0.0102)$ & & \\
\hline \multirow[t]{2}{*}{ Duration expansion GP* Output expansion } & & 0.0117 & & \\
\hline & & $(0.0121)$ & & \\
\hline \multirow[t]{2}{*}{ Duration consolidation AA } & & & $0.0293^{* *}$ & $0.0337^{* *}$ \\
\hline & & & $(0.0123)$ & $(0.0155)$ \\
\hline \multirow[t]{2}{*}{ Duration expansion AA } & & & 0.0214 & 0.00879 \\
\hline & & & $(0.0147)$ & $(0.0134)$ \\
\hline \multirow[t]{2}{*}{ Duration consolidation $\mathrm{AA}^{*}$ Output expansion } & & & & -0.00867 \\
\hline & & & & $(0.0168)$ \\
\hline \multirow[t]{2}{*}{ Duration expansion $\mathrm{AA}^{*}$ Output expansion } & & & & $0.0545^{* *}$ \\
\hline & & & & $(0.0262)$ \\
\hline Observations & 747 & 747 & 747 & 747 \\
\hline R-squared & 0.755 & 0.755 & 0.755 & 0.759 \\
\hline Country & 33 & 33 & 33 & 33 \\
\hline
\end{tabular}

Note: Robust standard errors in parentheses

${ }^{* * *} p<0.01,{ }^{* *} p<0.05,{ }^{*} p<0.1$

GP refers to fiscal episodes captured following Giavazzi and Pagano (1996) and AA refers to fiscal episodes captured following Alesina and Ardagna (1998) 
Table 5 Time-varying Okun's coefficient and types of fiscal consolidations

\begin{tabular}{|c|c|c|c|c|c|c|}
\hline & \multicolumn{6}{|c|}{ Time-varying Okun's coefficient (employment) } \\
\hline & (1) & (2) & (3) & (4) & (5) & (6) \\
\hline \multirow{2}{*}{ Central Bank policy rate $(-1)$} & $-0.244^{*}$ & $-0.240^{*}$ & $-0.250^{* *}$ & $-0.246^{* *}$ & $-0.247^{* *}$ & $-0.243^{*}$ \\
\hline & $(0.120)$ & $(0.122)$ & $(0.119)$ & $(0.120)$ & $(0.120)$ & $(0.121)$ \\
\hline \multirow[t]{2}{*}{ Employment protection legislation } & $-0.0967^{* *}$ & $-0.0972^{* *}$ & $-0.100^{* *}$ & $-0.0986^{* *}$ & $-0.0983^{* *}$ & $-0.0985^{* *}$ \\
\hline & $(0.0379)$ & $(0.0380)$ & $(0.0385)$ & $(0.0386)$ & $(0.0387)$ & $(0.0387)$ \\
\hline \multirow[t]{2}{*}{ Dummy output expansion } & & 0.00828 & & 0.00998 & & 0.00990 \\
\hline & & $(0.00845)$ & & $(0.00694)$ & & $(0.00705)$ \\
\hline \multirow[t]{2}{*}{ Expenditure-based consolidation GP } & $0.0507^{* *}$ & $0.0531^{* *}$ & & & & \\
\hline & $(0.0223)$ & $(0.0248)$ & & & & \\
\hline \multirow[t]{2}{*}{ Revenue-based consolidation GP } & 0.0143 & -0.0120 & & & & \\
\hline & $(0.0533)$ & $(0.0715)$ & & & & \\
\hline \multirow{2}{*}{$\begin{array}{l}\text { Expenditure-based consolidation } \\
\text { GP*Output expansion }\end{array}$} & & -0.00341 & & & & \\
\hline & & $(0.0281)$ & & & & \\
\hline \multirow{2}{*}{$\begin{array}{l}\text { Revenue-based consolidation } \\
\text { GP*Output expansion }\end{array}$} & & 0.0398 & & & & \\
\hline & & $(0.0548)$ & & & & \\
\hline \multirow[t]{2}{*}{ Expenditure-based consolidation AA } & & & $0.0395^{*}$ & $0.0534^{* *}$ & & \\
\hline & & & $(0.0205)$ & $(0.0239)$ & & \\
\hline \multirow[t]{2}{*}{ Revenue-based consolidation AA } & & & 0.0420 & 0.0234 & & \\
\hline & & & $(0.0266)$ & $(0.0335)$ & & \\
\hline \multirow{2}{*}{$\begin{array}{l}\text { Expenditure-based consolidation } \\
\mathrm{AA}^{*} \text { Output expansion }\end{array}$} & & & & -0.0353 & & \\
\hline & & & & $(0.0335)$ & & \\
\hline \multirow{2}{*}{$\begin{array}{l}\text { Revenue-based consolidation } \\
\text { AA*Output expansion }\end{array}$} & & & & 0.0386 & & \\
\hline & & & & $(0.0328)$ & & \\
\hline Observations & 747 & 747 & 747 & 747 & 747 & 747 \\
\hline R-squared & 0.752 & 0.752 & 0.751 & 0.752 & 0.752 & 0.752 \\
\hline Country & 33 & 33 & 33 & 33 & 33 & 33 \\
\hline
\end{tabular}

Note: Robust standard errors in parentheses

${ }^{* * *} \mathrm{p}<0.01,{ }^{* *} \mathrm{p}<0.05,{ }^{*} \mathrm{p}<0.1$

GP refers to fiscal episodes captured following Giavazzi and Pagano (1996) and AA refers to fiscal episodes captured following Alesina and Ardagna (1998)

Further, we also identify other factors that can affect the Okun's coefficients. In line with the literature, employment is less reactive to output at high degrees of labor market protection, while active labor market programs seem to adapt more the labor market to the needs of the firms, hence increasing the Okun's coefficient. A novel finding relates to the way the Okun's coefficient reacts to changes in the monetary policy rate. Increases in the rate are in fact almost always statistically significantly associated with reductions in the Okun's coefficients: this may reflect lower labor costs relative to capital, which would, in turn, increase labor demand but independently from aggregate demand.

Which policy implications can we draw from these results? First, fiscal adjustment (rather than specific ad hoc fiscal measures) can influence the way employment reacts to output. This finding adds a contribution to the literature which has traditionally 
found that consolidation is bad for employment. We in fact show that by increasing the Okun's coefficient consolidation is bad for employment at times of negative output gaps, but it would be positive in good times. Hence, consolidating when the economy is growing would enhance jobs. Cleary this finding omits the interaction between consolidation episodes and growth and the implication that a fiscal adjustment has on growth, which in turn can make consolidation episodes more likely associated with recessions than economic expansions. Second, we show that only a fiscal adjustment based on expenditure reduction would increase the Okun's coefficient. Third, fiscal policy is neither the only nor the main factor to affect the sensitivity of employment to output. Labor market institutions, such as employment protection legislation and the presence of active labor market programs, such as training or job rotation, do matter.

\section{Endnotes}

${ }^{1}$ For more analysis on the subject see also Pappa (2009), Cavallo (2005), and Ardagna (2007).

${ }^{2}$ The alternative specification includes the rate of change in output and changes in the unemployment rate.

${ }^{3}$ An alternative option could have been to use the policy-based approach à la Devries et al. (2011) and Romer and Romer (2010), which relies on descriptive historical information about policy-determined changes in fiscal variables. However, for the purpose of this analysis, we believe that the Fatas and Mihov procedure can be more easily applied to specific categories of expenditure.

${ }^{4}$ Available at http://personal.lse.ac.uk/ilzetzki/index.htm/Data.htm.

Competing interests

The IZA Journal of Labor Policy is committed to the IZA Guiding Principles of Research Integrity. The authors declare that they have observed these principles.

\section{Acknowledgements}

The authors would like to thank the anonymous referee for making this publication possible; Joao Jalles for sharing his data on fiscal episodes; Vitor Gaspar, Julio Escolano, Laura Jaramillo, Gilles Mourre, Prakash Loungani, Daniel Leigh, Nathaniel Arnold, Selim Elekdag, Manuela Goretti, Alvar Kangur, and all the participants of the 16th Banca D'Italia Fiscal Policy Workshop. They are particular grateful to Ethan Alt for excellent research assistance. Any errors are the authors' sole responsibility.

Responsible editor: Juan F Jimeno

Received: 14 November 2014 Accepted: 2 June 2015

Published online: 10 July 2015

References

Aghion P, Marinescu I (2008) Cyclical Budgetary Policy and Economic Growth: What Do We Learn from OECD Panel

Data?". In: Daron A, Kenneth R, Michael W (eds) NBER Macroeconomics Annual 2007, vol 22. University of Chicago Press, Chicago

Agnello L, Furceri D, Sousa RM (2013) How best to measure discretionary fiscal policy? assessing its impact on private spending. Econ Model 34:15-24

Afonso A, Agnello L, Furceri D (2010) Fiscal policy responsiveness, persistence and discretion. Publ Choice 145:503-30 Alesina A, Ardagna S, Perotti R, Schiantarelli F (2002) Fiscal policy, profits, and investment. Am Econ Rev 92:571-89

Alesina A, Ardagna S (1998) Tales of Fiscal Adjustments. Econ Policy October., pp 489-545

Ardagna S (2007) Fiscal policy in unionized labor markets. J Econ Dyn Control 31:1498-1534

Ball L, Leigh D, Loungani P (2013) Okun's Law: Fit at Fifty? Working Papers 18668 NBER Cambridge

Bassanini A, Duval R (2006) Employment Patterns in OECD Countries: Reassessing the Role of Policies and Institutions. Society, Employment \& Migration Working Papers 35 OECD Paris

Blanchard O (1997) The medium run. Brookings Pap Econ Act 2:89-158

Burnside C, Eichenbaum M, Fisher J (2004) Fiscal shocks and their consequences. J Econ Theor 115:89-117

Cahuc P, Zylberberg A (2004) Labor Economics. MIT Press, Cambridge

Card D, Kluve J, Weber A (2010) Active labour market policy evaluations: a meta-analysis. Econ J 120:452-77

Cazes S, Verick S, Al-Hussami F (2012) Diverging Trends in Unemployment in the United States and Europe: Evidence from Okun's Law and the Global Financial Crisis. Employment Working Papers, ILO

Cazes S, Verick S, Al Hussami F (2013) Why did Unemployment respond so differently to the Global Financial Crisis across countries? Insights from Okun's Law. IZA J of Lab Pol 2(10). 
Cavallo M (2005) Government Consumption Expenditures and the Current Account. Working Papers 2005-03 Fed Reserve Bank of San Francisco

Daly M, Fernald J, Jorda O, Nechio F (2013) Okun's Macroscope and the Changing Cyclicality of Underlying Margins of Adjustment. FRB San Francisco Working Paper 2013-32

Daly M, Fernald J, Jorda O, Nechio F (2014) Interpreting Deviations from Okun's Law. FRBSF Econ Letter 2014-12

Daly M, Hobijn B (2010) Okun's Law and the Unemployment Surprise of 2009. FRBSF Econ Letter 2010-07

De Mooij R, Keen M (2013) Fiscal Devaluation' and Fiscal Consolidation: The VAT in Troubled Times. In: Alesina A, Giavazzi F (eds) Fiscal Policy After the Financial Crisis. University of Chicago Press, Chicago

Devries P, Guajardo J, Leigh D, Pescatori A (2011) A New Action-Based Dataset of Fiscal Consolidations. Working Paper 11/128 IMF Washington

Disney R (2004) Are contributions to public pension programmes a tax on employment? Econ Pol 19/ 39:267-311

Estevão M (2007) Labor Policies to Raise Employment. Staff Paper 54/1 IMF Washington

Fatás A, Mihov I (2006) The macroeconomic effects of fiscal rules in the U.S. States. J Publ Econ 90:101-17

Fatás A, Mihov I (2003) The case for restricting discretionary fiscal policy. Q J Econ 118:1419-47

Fatás A, Mihov I (2001) The Effects of Fiscal Policy on Consumption and Employment: Theory and Evidence. Discuss Pap 2760 CEPR London

Finn M (1998) Cyclical effects of government's employment and goods purchases. Int Econ Rev 39(3):635-57

Gali J, Lopez-Salido JD, Valles J (2003) Understanding the Effects of Government Spending on Consumption. Working Pap 339 ECB Frankfurt

Giavazzi F, Pagano M (1996) Non-Keynesian effects of fiscal policy changes: international evidence and the Swedish experience. Swedish Econ Pol Rev 3(1):67-103

Gordon R (2010) Okun's law and productivity innovations. Am Econ Rev Pap Proc 100(2):11-5

ILO (2014) Global Employment Trends 2014. Risk of a jobless recovery? International Labour Office, Geneva

Ilzetzki, E (2011) Fiscal policy and debt dynamics in developing countries. Pol Res Working Paper Series 5666, The World Bank

International Monetary Fund (2010) World Economic Outlook: Rebalancing Growth. April, Washington

International Monetary Fund (2012) Fiscal Policy and Employment in Advanced and Emerging Economies. Washington Jaimovich N, Siu HE (2012) The Trend is the Cycle: Job Polarization and Jobless Recoveries. NBER Working Paper No. 18334 Jalles J (2014) Technical Note on Fiscal Consolidations and Labor Market Outcomes. IMF Fiscal Monitor October 2014. http://www.imf.org/external/pubs/ft/fm/2014/02/fmindex.htm

Knotek ES (2007) "How Useful Is Okun's Law?" FRB Kansas City Economic Review Q IV., pp 73-103

Krueger AB, Meyer BD (2002) Labor supply effects of social insurance. Handbook of Public Economics, vol 4, pages 2327-2392 from Elsevier.

Lane PR, Perotti R (2003) The importance of composition of fiscal policy: evidence from different exchange rate regimes. J Publ Econ 87:2253-79

Monacelli T, Perotti R, Trigari A (2010) Unemployment fiscal multipliers. J Mon Econ 97(5):531-53

Nickell S (1998) Unemployment: questions and some answers. Econ J 108:802-816

Nunziata L (2002) Unemployment, Labour Market Institutions and Shocks. Working Paper in Economics 2002-W16 Nuffield College Oxford

Okun A (1962) Potential Output: Its Measurement and Significance. Am Stat Soc, Proc Bus \& Econ Stat

Orlandi F (2012) Structural unemployment and its determinants in the EU countries. Econ Pap 455 European Commission Brussels

Organisation for Economic Co-operation and Development (2009) The Jobs Crisis: What Are the Implications for Employment and Social Policy. Employment Outlook OECD Paris

Owyang MT, Sekhposyan T (2012) Okun's law over the business cycle: was the great recession all that different? FRB of St. Louis Rev 94(5):399-418

Pappa E (2009) The effects of fiscal shocks on employment and the real wage. Int Econ Rev 50:217-44

Phelps ES (1994) Structural Slumps. Harvard University Press, Cambridge

Ramey V R (2011) Identifying Government Spending Shocks: It's all in the timing. Q J of Econ February 2011.

Romer CD, Romer D (2010) The Macroeconomic Effects of Tax Changes: Estimates Based on a New Measure of Fiscal Shocks.

Soegner L, Stiassny A (2002) An analysis on the structural stability of Okun's law: a cross-country study. Appl Econ 14:1775-1787

Turrini A (2013) Fiscal Consolidation and Unemployment: Does EPL Matter? A look at EU countries IZA Journal of Labor Policy $2 / 8$

Woo J, Bova E, Kinda T, Zhang YS (2013) Distributional Consequences of Fiscal Consolidation and the Role of Fiscal Policy: What Do the Data Say? IMF Working Paper 13/195 